\title{
Sitting on the Wall, Looking in: Some Reflections on the Critique of International Criminal Law
}

\author{
DOV JACOBS*
}

\begin{abstract}
This editorial explores some methodological difficulties that might be faced by the practice of the critique of international criminal law (ICL). It more particularly explores what it might mean to do an 'internal' critique of ICL, both on a disciplinary level and an intra-disciplinary level. The editorial also addresses two important issues: (i) the ambiguities of the normative agendas of critical legal scholars; and (ii) the difficulty of dialogue between critical legal scholars and positivists. The editorial concludes with the fact that while disciplinary dialogue might not always be possible, it will always take place on a personal, more complex level, in the Leiden Journal of International Law (LJIL) as elsewhere.
\end{abstract}

\section{Key words}

critique; disiplinary positioning; international criminal law; normative agendas; positivism

\section{INTRODUCTION: GETTING UP ON THE WALL}

By launching its practice of rotating editorials in the beginning of 2012, the Leiden Journal of International Law (LJIL) has opened a welcome and necessary space for board members to self-reflect about our editorial policies, and more generally our approach to international law. This has led to thought-provoking discussions on argumentative strategies, ${ }^{\mathrm{I}}$ the understanding of pluridisciplinarity, pluralism and generalism, ${ }^{2}$ the evolution of academic publishing, ${ }^{3}$ and the specific practices of particular fields of international law. ${ }^{4}$

* Senior Editor of the Leiden Journal of International Law; Assistant Professor of International Law, Leiden University [d.l.jacobs@law.leidenuniv.nl]. I would like to thank Jean d'Aspremont, Joe Powderly, Yannick Radi, Sara Kendall, Larissa van den Herik, Carsten Stahn, and Eric de Brabandere for comments on this editorial. All perceived errors are the result of the reader's methodological biases.

I J. d'Aspremont, 'ASPREMONTrticularly explore', (20I2) 25 LJIL 575; I. Venzke, 'What Makes for a Valid Legal Argument?', (2014) 27 LJIL, available on Cambridge Journals Online.

2 T. E. Aalberts, 'The Politics of International Law and the Perils and Promises of Interdisciplinarity', (2013) 26 LJIL 503; E. Van Sliedregt, 'Pluralism in International Criminal Law', (20I 2) 25 LJIL 847; Y. Radi, 'In Defence of "Generalism" in International Legal Scholarship and Practice', (20I4) 27 LJIL 303.

3 L. Van den Herik, 'Introduction: LJIL in the Cyber Age', (20I2) 25 LJIL I; F. Baetens and V. Prislan, 'The Dissemination of International Scholarship: The Future of Books and Book Reviews', (20I4) 27 LJIL 559; J. d'Aspremont and L. Van den Herik, 'The Public Good of Academic Publishing in International Law', (2013) 26 LJIL I; C. Stahn and E. de Brabandere, "The Future of International Legal Scholarship: Some Thoughts on "Practice", "Growth", and "Dissemination", (20I4) 27 LJIL I.

4 C. Stahn, "EDITORIAL: Between "Faith" and "Facts": By What Standards Should We Assess International Criminal Justice?', (20I2) 25 LJIL 25I; E. Van Sliedregt, 'Pluralism in International Criminal Law', (20I2) 
It is in this spirit of dialogue and self-reflection that the current editorial proposes some observations on the practice of the critique of international law, and more particularly the critique of international criminal law (ICL). The LJIL has a long tradition of diversity and has always been a place of choice for publishing notable critiques of international law. There is no doubt that this is part of the LJIL's identity. As has been accurately noted by others, ${ }^{5}$ the field of ICL, for a long time, and with a handful of exceptions, has escaped this critical approach. This is no longer the case, as recent publications show, including in the LJIL. ${ }^{6}$ Such development is more than welcome. The project of international criminal justice is in need of serious discussion about its own understanding of its history, its political and ideological dimensions, its conceptual flaws and ontological limits in dealing with mass atrocities. In this context, it therefore seems fitting to reflect on this growing scholarship of ICL critique and the methodological challenges that it can face.

While it is impossible in this editorial to cover all dimensions of the reflection, I aim here to begin with what should necessarily be the starting point of any epistemological discussion: the question of positioning. More particularly, I want to focus on the internal/external dichotomy often present in these debates.

This question of what is internal or external critique is important for two reasons. First of all, on a general level, I think we have lost the sense of borders in a number of ways in recent years. Disciplinary borders have been eroded by the enchanting calls of pluridisciplinarity. Professional borders have practically disappeared, notably in ICL, with the permanent (and possibly problematic) movement of personnel between academia, civil society, and practice at the courts in various capacities. Second of all, when it comes to critical legal scholars, it is obvious that they are notoriously difficult to pin down epistemologically. From Marx to Arendt, from Foucault to Derrida and Lacan, from postcolonial to feminist studies, the theoretical underpinnings of critical studies are very diverse. This difficulty is possibly due to the amorphous self-positioning of a number of critical legal scholars. When I first discussed the topic of this editorial with some colleagues, one of them said that I should not search too hard for a coherent use of the terms 'internal' and 'external' because it is the semantic diversity which made the critical field so appealing. To some extent this is part of the critical identity, as defined by Mégret: 'the critique of international criminal justice, then, must be thought of as an embodiment of the transgressive potential of critical theory, a living incarnation of the refusal to become pigeonholed'. 7 Yet, and it might be somewhat old school of me, I believe that disciplinary positioning and methodological clarity (i.e. pigeonholing) is important.

25 LJIL 847; S. Villalpando, 'On the International Court of Justice and the Determination of Rules of Law', (2013) 26 LJIL 243; V. Nerlich, Daring Diversity - Why There Is Nothing Wrong with "Fragmentation” in International Criminal Procedures', (2013) 26 LJIL 777.

5 C. Scwhöbel, 'Introduction', in C. Scwhöbel (ed.), Critical Approaches to International Criminal Law (20I4), I.

6 Recently in the LJIL, see T. Krever, 'International Criminal Law: An Ideology Critique. Leiden Journal of International Law', (2013) 26 LJIL 70I; M. D. Dubber, 'Common Civility: The Culture of Alegality in International Criminal Law', (20II) 24 LJIL 923; K. Campbell, 'The Making of Global Legal Culture and International Criminal Law', (2013) 26 LJIL I55.

7 F. Mégret, 'International Criminal Justice: A Critical Research Agenda', in C. Scwhöbel (ed.), Critical Approaches to International Criminal Law (2014) I7, at 46. 
Diversity in the use of terms does not mean that when someone employs a term its meaning should not be made clear. As a result, there is no better point of entry into this discussion on positioning that the internal/external dichotomy.

There is no easy answer to this question. Academic and disciplinary positioning is a complex matter, as illustrated by the following story. There is this patient, sitting on the wall of the mental institution he is living in, looking at people go by. For hours, he watches, in silence, as men, women, children, of all ages and build, walk by him with no interruption. Finally, he clears his throat, and calls out to a man just about to go past him: 'Sir, I'm just wondering, how many of you are there in there?' This anecdote shows that boundaries of the internal and external, and what lies beyond them depend not only on where the wall is, but ultimately on who is sitting on it.

Scholars have been grappling with this issue of positioning for some time now, and it is also present in the literature on the critical approach to ICL. ${ }^{8}$ It is not possible to enter into this debate comprehensively here, but I believe it is useful to distinguish two levels at which the dichotomy might come into play, which will structure this editorial: the disciplinary level (section 3) and the intra-disciplinary level (section 4). These methodological clarifications will lay the ground for some thoughts on the (im)possible dialogue between critical legal scholars and positivists (section 5). Before addressing these levels, it is however necessary to, from the outset, clarify my own positioning in approaching this discussion (section 2).

\section{A SHORT CLARIFICATION ON SELF-POSITIONING}

It does not seem controversial to claim that transparent self-reflection is fundamental for any author's understanding of his own biases and for the reader's better understanding of what is being argued. There is no doubt that critical distance and self-situationalism are indispensable attitudes when carrying out research.

In this sense, this editorial is not, and should not be perceived as falling in the long tradition of debates between 'crits' and 'non-crits'. More specifically, I am not speaking here as a positivist 'defending' ICL or positivism generally. Indeed, while I have no problem claiming to be a positivist, ${ }^{9}$ it does not mean that I am only that. As I further elaborate later on, I actually find this opposition between crits and positivists to be beside the point. These are two different and incommensurable methodologies to approach a given object of study, two different 'language games' ${ }^{\text {Io }}$, rather than conflicting approaches. While it is certainly not feasible to be both at the same time, from a synchronic perspective, it is perfectly possible to be both in sequence, from a diachronic point of view.

8 See C. Scwhöbel (ed.), Critical Approaches to International Criminal Law (2014), more particularly chapters by I. Tallgreen, S. Kendall, and M. Farrel.

9 D. Jacobs, 'Positivism and International Criminal Law: The Principle of Legality as a Rule of Conflict of Theories', in J. d'Aspremont and J. Kammerhofer (eds.), International Legal Positivism in a Post-modern World (20I2). Available at SSRN: <http://ssrn.com/abstract $=20463$ I I > . 
As a result, I would consider the following musings on critical approaches to ICL to be those of a critical legal scholar, talking to other critical legal scholars. They should hence be received in this spirit of dialogue rather than opposition.

\section{The InTERnal/EXTERnAl Dichotomy AT THE DISCIPLINARY LEVEL}

The first level where the internal/external dichotomy plays out is disciplinary, in the sense that the choice of the internal or external approach to an object of study broadly determines, or rather is determined, by broad disciplinary choices one makes as a researcher. Any discipline entails a conceptual framework and, as a result, adherence to certain paradigms associated with this framework. Schematically, an internal approach to law therefore implies accepting certain paradigms in relation to a number of issues (sources and rules of interpretation, for example), which brings the observer closer to what might be labeled 'legal science', while an external approach to law contextualizes and questions these paradigms, which brings the researcher closer to sociology. ${ }^{\text {II }}$

On this level of understanding of the dichotomy, I do not think that the concept of an 'internal' sociological approach to law is very intellectually satisfying. Indeed, the understanding of the object of study requires something of a distance from that object, an externalization of the observer.

When I first encountered astrophysics, I became obsessed with the question of what exactly it meant to say that the universe was expanding. More particularly, what I could not get my head around was the following interrogation: 'within what was it expanding?' As the universe is mostly a void of emptiness, was there another (different) void in which the universe was situated and in which it was growing? The best answer I ever got was from a university professor I had, who rather than actually answering the question, showed me that it made no sense given my own position as an observer. Indeed, I am within the universe I am describing, so cannot possibly point to the without of it and understand it. The question could only be answered if I were standing outside the universe and in a position to actually observe it expand in this other void.

I believe the same applies here. The claim to do an 'internal' sociological critique of ICL actually puts the person doing the critique in a methodological impasse as an observer, because there would therefore be no access to the context (social, political, philosophical) in which ICL is floating, which is, and should be, at the heart of any critical undertaking.

It is this maintained distinction between the internal and external dimensions of critique which justifies my claim that one can be both a positivist and a critical legal scholar. Indeed, it is in my view perfectly possible to assess the hegemonic tendencies of ICL and still engage in a technical discussion of how the Rome Statute can be interpreted in relation to a particular point of law.

I I On this disciplinary distinction, see M. Weber, Max Weber on Law in Economy and Society (I954), I I. 


\section{THE INTERNAL/EXTERNAL DICHOTOMY AT THE INTRA-DISCIPLINARY LEVEL}

Moving down one level from the disciplinary level, each discipline can adopt various understandings of the internal/external dichotomy. There is no need to delve too much here into the uses of this dichotomy in the legal science discipline, as it is not the object of the current editorial. ${ }^{\mathrm{I2}}$ More interesting is to see how this dichotomy plays out in the sociological approach to law. ${ }^{\mathrm{I} 3}$ There is quite a diversity in this respect, and as was rightly pointed out to me, it would be in vain to search for a coherent and uniform use of the dichotomy by sociologists. I do think that broadly speaking we use it in two different ways: as a methodological device (section 4.I) and as an expression of our emotional engagement with our object of study (section 4.2).

\section{I. The methodological distance from the object of study}

The first approach relates to our distance from the inner workings of our object of study. In that respect, one can schematically imagine a scale, with at one extreme, an approach to law that sees it as a sort of impenetrable black box and at the other extreme a full engagement with the actual legal framework and practitioners of the field and their logic. Those at the latter end of the scale can adequately be said to do an internal critique of law, possibly akin to Marx's immanent critique, defined in the following way:

In its most abstract and subjective moment, i.e., as immanent critique, critical theory identifies itself as a conceptual movement which stands over and against orthodoxy and its view of the world. Whether it takes the form of philosophical discourse, expresses itself in aesthetic analysis, or assumes its more familiar form - that of a philosophically-grounded sociology - critical theory in its methodological moment always acknowledges that its object of realization lies outside itself, in the theoretical orthodoxies and prevailing practices of an era. Thus, if critical theory is to realize itself materially, it must of necessity enter into meaningful dialogue with the reifying orthodoxies of an age. ${ }^{\mathrm{It}}$

In relation specifically to a critique of 'ICL', I would have a preference for such a methodology, which aims at deconstructing, after having first understood, the internal workings of a discipline. ${ }^{15}$ Indeed, when one looks at the literature in this field, it often appears that the object of study, 'ICL', is never defined. As a result, it is in fact not very clear what the methodological positioning of a number of authors is and they seem often to be undertaking a critique of law generally, political institutions, power relations, or of the international criminal justice project. There is

I 2 On the particular use of the internal/external dichotomy in Hart's work, see S. J. Shapiro, 'What is the Internal Point of View', (2006) 75 Fordham Law Review I 57.

I3 I acknowledge that uncritically (no pun intended) putting the Critical Legal Studies movement in the sociological discipline carries its own problems. Indeed, the relation of critical theory to traditional sociology has equally been the object of considerable epistemological debate. On this see D. Harvey, 'Introduction', (I990) 33 Sociological Perspectives I.

I4 Harvey, supra note I3, at 5 .

I5 This need not necessarily be the case. For example, a criminological evaluation of the functions and objectives of ICL does not technically need to be internal within the meaning given here. See I. Tallgren, 'The Sense and Sensibility of International Criminal Law', (2002) I3 EJIL 56 I. 
nothing wrong with that of course. But it does raise the question of what specifically a critique of 'ICL' is and how can it be conducted from an internal perspective.

Essentially, a methodologically sound internal critique of ICL needs to take the content of the law seriously in order to understand how it relates to the other considerations that particular critiques brings into play (be in politics, sociology, history, philosophy, etc.). Too often, broad statements are put forward about the politics of law, without careful discussion of how the politics actually come into play within the legal framework. Without the second part of the process, one is left with the crushingly obvious statement that 'law is political' which does not bring us any closer to an understanding of exactly how law and politics interact.

Without this refinement, we are left with a rather simplistic 'political hypothesis', equivalent to the 'God hypothesis' in science, ${ }^{16}$ which might explain everything but in fact predicts nothing, and is therefore a useless methodological tool. ${ }^{17}$ The idea here is of course not to deny that there are politics involved at every step of the legal process, from its creation, to its implementation and interpretation. However, this claim, in order to be something more than a blanket critique, must be accompanied by an actual discussion of the legal framework and how it reflects the politics of law. $^{\text {I8 }}$

This editorial cannot provide an extensive list of ways in which this can be done. It suffices to put forward one illustration: the necessity to understand what can be called the 'space of discretion' within legal frameworks, i.e. the amount of leeway given to particular legal agents to adopt a certain conduct or make a certain decision. This in turn gives a better image of where exactly political and ideological choices come into play in the legal process, and who expresses them (states, judges, the prosecutor ...). For example, it is much more believable to focus attention on a prosecutor of an international tribunal who has some discretion in the choices of places where he will open investigations (International Criminal Court), as opposed to a prosecutor who has no discretion in that respect (ad hoc tribunals). In the former case, the opening of an investigation might reflect political choices on the part of the Prosecutor herself, while in the latter case the choice of the situation might be more indicative of an institutional political bias. Such refinement requires some knowledge of the actual legal framework.

Ultimately, a relevant critique of ICL should therefore take the content of the law seriously in order to understand exactly how it allows for political concerns to be taken into account or ignored at various stages of the proceedings.

I6 On this see R. Dawkins, The God Delusion (2008), particularly Part 2.

I7 The expression is borrowed here from French scientist Laplace, who allegedly responded to Napoleon's surprise at the absence of God in his physics treaty by saying that 'God is not a hypothesis I have needed so far', adding that this hypothesis while explaining everything, would help to predict nothing.

I8 For an example of this, see T. Krever, 'Dispensing Global Justice', (2014) 85 New Left Review 67. The article makes sweeping statements about international justice as a tool to take attention away from Western (i.e., US) crimes (which is possibly partly true), but with no real understanding of the legal framework or the case law of the courts (which removes any credibility of the article for anyone who knows a little bit about ICL, even if they were to agree, as I do, on the general approach or some specific points highlighted by the author). 


\subsection{The emotional distance from the object of study: The normativist crit and its difficulties}

The second way this dichotomy might be used is on a more personal and psychological level. Some critical legal scholars might not be using it as a methodological device at all, but might rather be expressing their own emotional relation to the object of study. In essence, the internal/external dichotomy would separate those who still want to believe in the system, or at least in the fact that it can be improved or reformed, to some extent, from those who are purely describing it out of intellectual curiosity.

I would tend to be in the latter category. In this sense, I do not believe that a critical project is necessarily political. ${ }^{\text {I9 }}$ I am perfectly content to identify the methodological biases of ICL practitioners ${ }^{20}$ and alleged failings of the international criminal justice project, ${ }^{2 \mathrm{I}}$ without putting forward a normative agenda for change. But the fact is that it is very obvious that a lot of critical legal scholars have a deep sense of justice/injustice that drives their research. These might be called 'normativist crits' and three observations need to be made in relation to this category.

The first is rather obvious: any normative project should be transparent about its normative agenda. ${ }^{22}$ But this is only the starting point. Second of all, normativist crits must also be aware of the risks of complicity with their object of research once they engage emotionally with $i^{23}$ and explain how their ambition is really that much removed from the 'effectiveness criticism' that a number of critical legal scholars seem to reject, 'which focuses on effectiveness and the strengthening of the existing structures'24 and is seen as 'a sort of adjunct of international criminal justice'. ${ }^{25}$ Of course, effectiveness criticism does not contest the foundations of the discipline as a sociological critique might, but there is a shared desire for the system as a whole to be made better, albeit in a different way, based on a different sense of justice/injustice, and with different ideas about the tools to achieve normative goals. In other words, normativist crits are just trying to make effective their own normative agenda, in the same way that the uncritical ICL practitioners are trying to fight impunity through the International Criminal Court. The third, and possibly most important observation is that normativist crits must tackle the methodological difficulty of reconciling their own normative agenda within an intellectual framework that will undermine its validity or the possibility of its realization. For example, a critique that notes, probably accurately, the inherent propensity of law to perpetrate structures of power and oppression can hardly call for the legal framework to change. More profoundly, from a critical perspective, how does one justify

Scwhöbel, supra note 5 , at 6 .

D. Jacobs, 'The Mythical Unities of International Criminal Law: Some Thoughts on Perisic, Taylor and Sainovic', (2014) QIL, Zoom-in 3, 23-39.

D. Jacobs, The Failures of International Criminal Justice (And Why They Don't Matter), Speech delivered at Bochum University, 22 October 2013 (on file with the author).

Scwhöbel, supra note 5 , at 3 .

M. Farrell, 'Critique, Complicity and I', in C. Scwhöbel (ed.), Critical Approaches to International Criminal Law (2014), at 96.

Scwhöbel, supra note 5, at 3.

Mégret, supra note 7 , at I 8. 
one's own ideological biases when adopting a methodology that casts doubt, again rightly so, on all ideological endeavours? ${ }^{26}$ Only if these obstacles are overcome can there be an effective internal critique of ICL, i.e., a critique that ultimately aims at influencing its inner structures.

\section{The illusion OF Disciplinary Dialogue?}

The previous methodological clarifications explain why I do not really understand the tension that there continuously seems to be between critical legal scholars and positivists. In my view, it is a false debate, because we are not doing the same intellectual work with the same methodology, and, as said previously, I think that one can do both, if not at the same time. I would tentatively suggest that the origin of this false debate once again relates to an aspect of the internal/external dichotomy. The reason that critical legal scholars and positivists in the field of international law seem to be competing for the same audience today is that the critique of international law was brought to the attention of international lawyers by people within their ranks. In this sense, it is indeed an internal critique, because of their initial position within the box. From there grew the illusion that this debate was all taking place within a somewhat shared discursive, methodological, and epistemic framework, and out of that illusion grew the idea that we need to discuss how critical legal scholars and positivists should interact, be it through confrontation or dialogue. This is in my view epistemologically inaccurate, as the Critical Legal Studies (CLS) movement, as I have tried to suggest above, cannot be in the same epistemic box as its object of study.

Once this is said, where does this leave us? This could be seen as a damning nail in the coffin of possible dialogue between the two communities. This is indeed the case to a large extent, and calls for some form of 'ecumenism' ${ }^{27}$ between positivism and other approaches to international law might be somewhat optimistic. However, while disciplinary separation does carry with it certain limitations to dialogue, which we should accept, it does not mean that all communication is impossible. The following closing thoughts are merely general illustrations of where this (imbalanced) equilibrium might be struck.

In terms of limitations to dialogue, each discipline should accept the other side's separate disciplinary existence. This has a number of consequences. On a fundamental level, it should be recalled that:

[D]isciplines are social constructs, subject to the direction and whimsy of its participants - though of course not any whimsical direction is open to them. A discipline's continuity and evolution depends, like all traditions, on the sustainability of a core set of beliefs, rules or 'entrenched ideas'. But it is also constituted by continuous conflict over interpretations of its identity, its limit and its potential. Epistemic disagreements

26 On the ambiguities of the realist approach in that respect, see M. Koskenniemi, The Politics of International Law (20II), 89-I03. On Koskenniemi's own ambiguities in relation to his liberal critique, see E. Jouannet, 'Koskenniemi: A Critical Introduction' in the same volume at 22-32.

27 J.d'Aspremont, 'Reductionist Legal Positivism in International Law',(20I2) Io6 American Society of International Law Proceedings 368 , at 370 . 
are key to the discipline's sustenance, renewal and fortitude. But it is only where such disagreements destabilise the core beliefs or rules of a discipline that it risks descending into incoherence and rupture. ${ }^{28}$

In other words, the practice of legal science involves certain methodological choices which condition its very existence and at some point, disciplinary dialogue can only go so far before lapsing into self-destruction.

An illustration of this is the idea of linguistic indeterminacy. Any lawyer with a bit of sense knows that law is not mechanical and can be subject to a wide range of interpretations. As is usually said: 'lawyers can argue anything'. In this sense, lawyers do not need Wittgenstein or Foucault to know about this. However, there is only a certain amount of indeterminacy that can be accepted within legal science, before it loses what is its disciplinary core. Within legal science, there is a range of accepted social/disciplinary meanings and argumentative techniques which come to curtail the indeterminacy of language. As a result, the response that some critical legal scholars give to lawyers when they claim that a legal term means $\mathrm{X}$, that this is a socially constructed and contingent meaning, is the equivalent of someone being asked to put the plates on the table, answering that a 'table' is only a 'table' because of the subjective and socially arbitrary choice to call it that way: it is true, but it is totally irrelevant in that context and for the purposes of locating the place to put the plates. ${ }^{29}$ For lawyers to accept internalizing the inherent indeterminacy of language as a part of their legal methodology would be to accept the death of legal science. This might be a good outcome, but critical legal scholars cannot expect lawyers to make it happen. This is an example of what has aptly been labeled 'destructive interdisciplinarity'. ${ }^{30}$

Linked to this is the idea that everyone can and should do critique, irrespective of their position 'inside' or 'outside' the system. This is probably a too simplistic position. Indeed, exercising a certain function or being situated at a certain location within or outside the ICL framework carries with it varying degrees of critical and methodological freedom. This is most notably true for practitioners of ICL. For example, the Prosecutor of the International Criminal Court has the function of initiating proceedings in conformity with the Rome Statute, in the same way that judges are bound to apply the legal framework when determining their jurisdiction or passing judgment on the guilt or innocence of a particular individual. ${ }^{3 \mathrm{I}}$

In terms of possible interaction, I do believe that a good critique of law will necessarily be one that actually understands how the law works in its technical aspects and can possibly benefit from the input of the practitioners in the field. ${ }^{32}$

S. Singh, 'Narrative and Theory: Formalism's Recurrent Return', (2014) 84 British Yearbook of International Law 303 , at 323 .

29 The example also works with the 'plates' rather than the 'table'.

30 S. Singh, 'International Law as a Technical Discipline: Critical Perspectives on the Narrative Structure of a Theory', in J. d'Aspremont, Formalism and the Sources of International Law (2013), 243.

3I This does not mean that there does not exist a space within the legal framework for expressing political preferences, a space which it is important to identify and understand (see supra, section 2). However, the expression of these preferences is still ultimately bound by the outer limits of the legal framework, which constrains it both legally and methodologically.

Supra, section 2. 
As for the dialogue in the other direction (from outside the box back into it), it really depends on the nature of the critique. Some critiques of ICL, or international law generally, are so radical about the failings of any legal regime that, however accurate they are, they cannot be heard inside the box. Indeed, some 'thinkers seem to be saying that the entire legal tradition is rotten, that it is built on a faulty or deceptive edifice; so any tinkering within the system that is short of a revolution will be as fruitless as rearranging deck chairs on the Titanic'. ${ }^{33}$ And that is fine, but this precludes any interaction, as we should not expect the lawyers to stop being lawyers, because that is their job. Other critiques that identify more specifically areas of law and legal mechanisms that do reproduce patterns of injustice can possibly be internalized by lawyers and policy makers. Such interaction obviously requires a less radical state of mind on the part of the critical thinker. ${ }^{34}$ On a more general level, as pointed out above, I do think that the two methodologies are complementary in understanding law and legal processes. It should be stressed however that this complementarity does not necessarily imply dialogue between the disciplines, but rather some awareness of their existence.

In a sense, I am arguing for a reductionist form of CLS, which parallels d'Aspremont's call for a reductionist legal positivism, ${ }^{35}$ which implies a somewhat humble approach at to the core tenets of the discipline and what it can achieve. As a result, this means that we have to accept that the two reduced disciplinary circles never actually meet, or only in a minimal way, which avoids the risk of interdisciplinary colonization. ${ }^{36}$

\section{Conclusion: Getting DOWn fROM the WAlL}

Of course, while I believe that the discussion proposed here is valuable, things are not this simple and this editorial presumes a level of methodological clarity and rationality that leaves out not only the tensions within disciplinary debates, but more importantly the individual intellectual, psychological and emotional processes which led us all to do what we do in the way we do it.

As a result, no person can obviously be reduced to one epistemic identity. We are (or should be) all struggling with our own inconsistencies and limits. In a sense, we are all sitting on a wall looking into a somewhere that is not defined by where it is, but rather by where we are and by where we came from. Of course, this wall metaphor has its limits as there is only so much time that we can actually spend on

33 D. E. Litowitz, 'Internal Versus External perspectives on Law: Towards Mediation',(I99-I 999) 26 Florida State University Law Review I 27, at I4I.

34 See, e.g., D. Kennedy, 'Legal Education as Training for Hierarchy', in D. Kairys (ed.), The Politics of Law (I998), 54 at 62. ('What is needed is to think about law in a way that will allow one to enter into it, to criticize it without utterly rejecting it, and to manipulate it without self-abandonment to their system of thinking and doing'). For such a conciliatory approach in ICL see D. Robinson, 'A Cosmopolitan Liberal Account of International Criminal Law', (2013) 26 LJIL I 27.

36 Singh, supra note 28 , at 322 . 
a wall. ${ }^{37}$ While this editorial focused on that particular moment of elevation, we are obviously most of the time standing on either side of the wall, possibly unaware of its presence.

But the fact remains that the wall is a welcome occasional meeting point for selfreflection on our own biases and incoherencies. Ultimately, it is these incoherencies that might explain why dialogue, in the LJIL as elsewhere, will always be necessary and, more importantly, possible.

37 Maybe a point that some crits who do not want to be pigeonholed would try to make is that they are in fact always sitting on the wall. If so, it is a very precarious situation to be in and possibly a very high price to pay to be able to claim intellectual uniqueness. 